never unapproachable, and once his attention was captured he could be most helpful. To colleagues and students alike he was uniformly genial and unaffected. Undoubtedly Bolton was fortunate in the times in which he began his professional work, for seldom can conditions have been more favourable for the combination of clinical practice and research. The solid bases of descriptive medicine and morbid anatomy had been laid, and physiology had sufficiently ad. vanced to become applicable to clinical problems. The methods of approach and the techniques required for clinical research differed little from those used in routine practice, and the extra knowledge necessary for research, at that stage in the development of medicine, was not yet so large as to demand the whole of a man's attention and time. The business of living was also easier, and consultants could afford time for other activities than practice. Such a coincidence of conditions could only be transient, and with its disappearance the combination of private consultant and research worker began to disappear, so that now it is hard to find an example, outside certain specialties. Yet, if our medical schools are not to become simply technical institutes, if some. thing more than technology is required in the training of a physician, then effective steps to prevent the separation of medical research and practice must be taken.

It must again be made possible for men like Bolton to devote adequate time to investigating their subjects. Undoubtedly the conditions now required will be very different from those which sufficed in the spacious Edwardian days when he flourished; but the ideal which inspired Bolton is still there, and, given the opportunity, its devotees will fulfil it.

\section{H. P. HIMSWORTH}

\section{Dr. Emily Berridge}

Dr. Emily M. Berridge, who died on October 8, in her seventy-sixth year, has slipped away from the world of science as unobtrusively as she lived in it. But live in it she did her whole life long, devoting her life to research from her youth, when she was encouraged by her father, himself an experimenter, and by her head-mistress, Miss Arnold of the Dulwich High School, to make science her career. In 1894 she went up to the Royal Holloway College as an entrance scholar in natural science, and it was here she began research work in botany (under Prof. Margaret Benson).

Dr. Berridge's published researches fall into two distinct groups. The early papers, studies on fossil plants, and on the groups Gnetales and Amentiferæ, published mainly in the Annals of Botany and the New Phytologist between 1905 and 1914, bear the mark of her early training in Dr. Benson's special field of botany. The later papers, studies in bacteriosis published in the Annals of Applied Biology between 1921 and 1930, recall her colleague Dr. Paine, in whose laboratory at the Imperial College of Science and Technology, London, she worked during these years. The explanation of this complete change in type of research is to be found in her war work, 1914-19, which was done with Dr. Ernest Glynn in the Thompson Yates Laboratory, University of Liverpool, on agglutination of dysentery bacteria and the preparation of serum.

Not only did Dr. Berridge carry out research herself but she also gave generously of her time, thought and money to young postgraduates just starting on research. The extent of her generosity will never be known, for her gifts were mostly made anonymously. She was shy and diffident about her own work and so truly humble that only those who worked with her knew how good it was; just as only those who served with her on research committees knew of the quick grasp of essentials, the sound judgment and the unassailable integrity of mind and purpose that she brought to the discussion of any problem.

E. M. BLACKWHLL

\section{Dr. André Kling}

Dr. André KuIng died on August 8, 1947, at the age of seventy-five. Receiving his education and early training in Paris, he.was appointed in 1911 director of its municipal laboratory. The frauds in food and wine, to restrain which the laboratory had been founded under Charles Girard, were now declining, but the First World War opened to the laboratory new fields of activity. The Explosives Service, initiated by Girard during the anarchist bomb panics, was now developed for the disposal of unexploded German missiles; and Kling's leadership was an example of personal courage no less than of professional ability. His experience and success in this field led to his appointment as scientific adviser to the French General Staff. Working in this capacity at the front line on explosives and war gases, he earned the Croix de Guerre and membership of the Legion of Honour.

After the War, Kling interested himself effectively in the internationalization of analytical methods and standards. During the nineteen-twenties he presided over the Intermational Union of Chemistry's Commission on Pure Substances for Research, to which he presented a report which led to the inception in 1928, under his presidency, of a separate Commission of Analytical Chemistry. In France, he was a pioneer in the formation of the Société de Chimie Industrielle, in which he held office on various occasions.

In actual chemical work, the name of Kling is perhaps most readily associated with the analytical separation of the metals of Groups III and IV. He was also, however, the author of numerous papers on methods of food examination, and, outside the analytical field, on the high-temperature hydrogenation of aromatic compounds. This work, even after his official retirement, continued to the end of a life wholly dedicated to his profession.

\section{Prof. J. Masson Gulland, F.R.S.}

Dr. Jesse P. Greenstein, chief of the Biochemistry Section, U.S. Public Health Service, writes: "The loss of Prof. J. M. Gulland to the scientific world is deeply regretted by his colleagues in the United States who knew the man and admired his personality and achievements. Gulland was one of a group of distinguished foreign guests at the Cold Spring Harbor Symposium held in June 1947. He was easily the dominant figure at that conference, and the charm and ease of his manner, his gentle critical spirit, together with the scholarliness and incisiveness of his thinking, evoked general admiration and affection. Gulland's investigations in the field of the nucleic acids revealed a meticulous and sound approach, and were of great interest and still greater promise. It is indeed a sad misfortune that we should have lost him." 